\title{
Progesterone in women with arrested premature labor, a report of a randomised clinical trial and updated meta-analysis
}

\author{
Stephen Wood ${ }^{1 *} \mathbb{D}$, Yacov Rabi ${ }^{2}$, Selphee Tang ${ }^{1}$, Rollin Brant $^{3}$ and Susan Ross ${ }^{4}$
}

\begin{abstract}
Background: Progesterone may be effective in prevention of premature birth in some high risk populations. Women with arrested premature labor are at risk of recurrent labor and maintenance therapy with standard tocolytics has not been successful.

Methods: Randomized double blinded clinical trial of daily treatment with $200 \mathrm{mg}$ vaginal progesterone in women with arrested premature labor and an updated meta-analysis.

Results: The clinical trial was terminated early after 41 women were enrolled. Vaginal progesterone treatment did not change the median gestational age at delivery: $36+2$ weeks versus $36+4$ weeks, $p=.865$ nor increase the mean latency to delivery: 44.5 days versus 46.6 days, $p=.841$. In the updated meta-analysis, progesterone treatment did reduce delivery $<37$ weeks gestation and increase latency to delivery, but this treatment effect was not evident in the high quality trials: (OR $1.23,95 \% \mathrm{Cl} 0.91,1.67)$ and $(-0.95$ days, $95 \% \mathrm{Cl}-5.54,3.64)$ respectively.
\end{abstract}

Conclusion: Progesterone is not effective for preventing preterm birth following arrested preterm labor.

Keywords: Premature labor, Maintenance tocolysis, Progesterone, Clinical trial, Meta-analysis

\section{Background}

A significant number of women who eventually deliver prematurely present with threatened preterm labor. Despite the success of initial tocolysis [1], many will develop recurrent labor and go on to deliver prematurely. These patients represent an opportunity for the secondary prevention of prematurity. Unfortunately, drugs such as calcium channel blockers [2], non-steroidal anti-inflammatories [3] and antosiban [4] have not been clearly effective in maintenance tocolysis. Based on the success of progesterone treatment in preventing prematurity in some high risk populations [5, 6], we initiated a clinical trial of progesterone in women with arrested premature labor. We report the results of our trial of treatment with $200 \mathrm{mg}$ vaginal progesterone in women with arrested premature labor along with a meta-analysis of all types of progesterone for maintenance tocolysis.

\footnotetext{
* Correspondence: Stephen.wood@albertahealthservices.ca

${ }^{1}$ Department of Obstetrics and Gynaecology, University of Calgary, 4th Floor, North Tower, Foothills Medical Centre 1441 - 29th Street NW, Calgary, AB T2N 2T9, Canada

Full list of author information is available at the end of the article
}

\section{Methods}

Randomized Clinical Trial

Women presenting in premature labor to our center, the Foothills Medical Center in Calgary, Alberta, Canada, were approached by the primary investigator or study nurse for enrollment in the study. Inclusion criteria were women with gestational age $23^{0}-32^{6}$ weeks with symptomatic contractions successfully arrested for at least $12 \mathrm{~h}$ with tocolytics or those with contractions that spontaneously resolved but had a positive vaginal fetal fibronectin ( $>50 \mathrm{ng} / \mathrm{ml}$ ). Exclusion criteria were multiple pregnancy, placenta previa, preterm premature rupture of membranes (PPROM) at presentation and any contraindication to progesterone use. Consenting subjects were allocated by a randomization schedule developed by the trial statistician (R.B) using a random number generator and in random blocks of 2 or 4 . Randomization was stratified into two strata to ensure balance in these important risk factors for preterm birth between the two groups: (i) tocolytic use; (ii) no tocolytic use. The primary investigators and study 
personnel involved in recruitment were not aware of the allocation sequence. Treatment packs containing $200 \mathrm{mg}$ tablets of either micronized progesterone (Utrogestan, Besins-Healthcare) or an identical placebo were dispensed by a central research pharmacy. The treatment duration was from the time of randomization until $35^{6}$ weeks gestation or until delivery of the fetus, if sooner. The primary outcomes of the trial were gestational age at delivery and latency to delivery. Outcome assessors were blind to treatment status. The expected date of delivery recorded in the chart, at the time of randomization, was used subsequently to determine gestational age at delivery. Secondary outcomes included delivery $<37$ and $<35$ weeks gestation, recurrent premature labor and neonatal outcomes including death, broncho-pulmonary dysplasia, intraventricular hemorrhage, necrotizing enterocolitis, respiratory distress syndrome, hyperbilirubinemia, sepsis and need for ventilation. Our planned sample size was 60 per group, based on a $90 \%$ power to detect a 2 week difference in gestational age at delivery [7] at a significance level of $(0.05)$. The outcomes were analyzed by intention to treat with the subjects remaining in the group they were randomized to, regardless of compliance with treatment. The gestational age at delivery were compared between the two groups using the Mann-Whitney $U$ test, as the data was skewed. Mean latency to delivery was assessed using the student's $t$-test. For preterm delivery $<37$ weeks and $<35$ weeks, a relative risk was calculated and statistical significance assessed by Fisher's exact test. The other secondary outcomes were analyzed similarly. The trial was registered at ClinicalTrials.gov (NCT01286246). The trial was reported following CONSORT guidelines.

\section{Meta-analysis}

The primary research question of the meta-analysis was: Does maintenance tocolysis with progesterone prevent prematurity, ( $<37$ and $<34$ weeks gestation) or extend latency to delivery? The secondary question was: Does treatment reduce perinatal mortality. A literature search up to April 2015 was performed using the following databases and MeSH terms: Medline (Tocolytic Agents, or Tocolysis, or Obstetric labor, premature and Progesterone and Clinical trial), Embase (Premature labor or Tocolysis and Progesterone and Clinical trial), PubMed (premature labor and Progesterone and Clinical trial) and the Cochrane Central Register of Controlled Trials (Obstetric labor, premature or Tocolysis and Progesterone). These searches were subsequently updated in October 2015 and again in April 2016 and February 2017. The identified abstracts and appropriate manuscripts were reviewed by two of the authors (SW, SR). Studies were included if they were clinical trials of progesterone in women with premature labor following tocolysis. Risk of bias and quality of the manuscripts was judged independently by the reviewers using standard criteria [8]. All studies were graded as high or low quality based on four key quality indicators: adequate

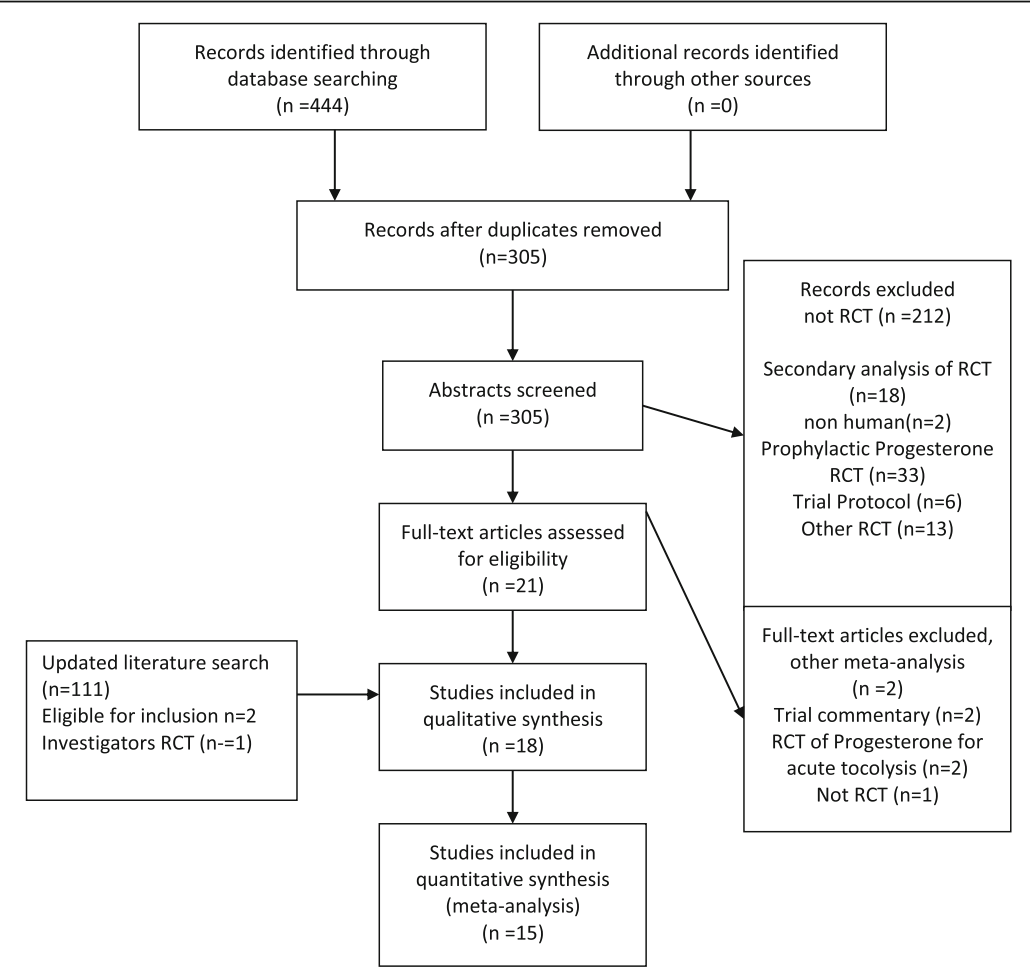

Fig. 1 Flow diagram of studies included in the meta-analysis 
randomization and allocation concealment, blinding, limited losses to follow up $(<20 \%)$ and intention to treat analysis. Studies that were deficient in any of these areas were graded as low quality. Studies were not included in the quantitative summary analysis unless intent to treat analysis was presented or could be calculated from the available data. Authors were contacted to obtain missing data. The primary outcomes of the meta-analysis were premature delivery $<37$ and $<34$ weeks gestation and latency to delivery. Quantitative analysis with a fixed and random effects models were performed with RevMan 5.1. Statistical assessment for heterogeneity was performed and considered statistically significant if $p<.05$. Random effects models were used for analyses with significant heterogeneity. A subgroup analysis by type of progesterone (oral, vaginal or intra-muscular) and by trial quality was planned a priori. This analysis was done with a fixed effects model even if there was significant heterogeneity between high and low quality studies then pooled analysis of all studies would not be meaningful. The metaanalysis results were reported as per PRISMA guidelines.

\section{Results}

Randomized Clinical Trial

Between February 2011 and February 201441 women were enrolled in the trial. Unfortunately, this did not meet our recruitment goals. Furthermore, the study drug we had been provided reached an expiry in August 2014 and the provider had changed its progesterone product. To continue the trial a new application would have been necessary to Health Canada. Given all these factors a decision was made to terminate the trial.

The patient characteristics are provided in the Appendix Table 3 and were adequately balanced between the two groups. The flow diagram for the trial is provided in Appendix Figure 8. There were no losses to follow up nor post randomization exclusions. Treatment with progesterone, compared to placebo, did not result in an increase in median gestational age at delivery: $36^{+2}$ weeks versus $36^{+4}$ weeks, mean difference $-.0^{2}\left(-3^{+1}\right.$ to $\left.2^{+3}\right)$ nor in mean latency to delivery: 44.5 days versus 46.6 days, mean difference -2.1 $(-22.8,16.8)$. No significant differences were detected in any

Table 1 Study characteristics of randomized controlled trials of progesterone for maintenance tocolysis

\begin{tabular}{|c|c|c|c|c|c|}
\hline Study & Year & Country & $\begin{array}{l}\text { Number of } \\
\text { Subjects }\end{array}$ & Study Population & Treatment/controls \\
\hline Areia [22] & 2013 & Portugal & 52 & $\begin{array}{l}\text { 24-34 weeks gestation cervical length } \\
\leq 25 \mathrm{~mm} \text { after tocolysis with antosiban. }\end{array}$ & $\begin{array}{l}\text { Progesterone } 200 \text { mg vaginally/No } \\
\text { treatment. }\end{array}$ \\
\hline Borna [21] & 2008 & Iran & 70 & $\begin{array}{l}\text { 24-34 weeks gestation after tocolysis } \\
\text { with MgSO4, cervical dilation } \leq 2 \mathrm{~cm} \text {. }\end{array}$ & $\begin{array}{l}\text { Progesterone } 400 \text { mg vaginally/No } \\
\text { treatment. }\end{array}$ \\
\hline Choudhary [13] & 2014 & India & 90 & $\begin{array}{l}\text { 24-34 weeks gestation after tocolysis } \\
\text { with nifedipine, cervical dilation }>1 \mathrm{~cm} \text {. }\end{array}$ & Progesterone 200 mg orally/Placebo \\
\hline Facchinetti [15] & 2007 & Italy & 60 & $\begin{array}{l}25-34 \text { weeks gestation after tocolysis } \\
\text { with antosiban. }\end{array}$ & $\begin{array}{l}\text { 17-hydroxyprogesterone caporate } \\
341 \text { mg IM q } 4 \text { days/ No treatment }\end{array}$ \\
\hline Kamat [20] & 2014 & India & 110 & $\begin{array}{l}<37 \text { weeks gestation, after tocolysis } \\
\text { with nifedipine. }\end{array}$ & $\begin{array}{l}\text { Progesterone } 400 \text { mg vaginally/ } \\
\text { nifedipine } 20 \text { mg q8h. }\end{array}$ \\
\hline Lotfalizadeh [24] & 2013 & Iran & 110 & $\begin{array}{l}\text { 26-36 weeks gestation, after tocolysis } \\
\text { with nifedipine or MgSO4 }\end{array}$ & $\begin{array}{l}\text { Progesterone } 400 \text { mg vaginally, or } \\
\text { 17-hydroxyprogesterone caporate } \\
250 \text { mg IM/No treatment. }\end{array}$ \\
\hline Noblot [12] & 1991 & France & 44 & $\begin{array}{l}<37 \text { weeks gestation, regular contractions, } \\
\text { tocolysis with ritodrine }\end{array}$ & $\begin{array}{l}\text { Progesterone } 400 \text { mg orally, started } \\
\text { before cessation of contractions/Placebo }\end{array}$ \\
\hline Palacio [19] & 2013 & Spain & 265 & $\begin{array}{l}24-34 \text { weeks gestation, cervical length } \\
\leq 25 \mathrm{~mm} \text {. } \\
\text { Arrested preterm labour, tocolytic } \\
\text { not specified }\end{array}$ & Progesterone 200 mg vaginally/Placebo. \\
\hline Rozenberg [14] & 2012 & France & 188 & $\begin{array}{l}24-31 \text { weeks gestation and cervical } \\
\text { length }<25 \mathrm{~mm} \text { after tocolysis }\end{array}$ & $\begin{array}{l}\text { 17-hydroxyprogesterone caporate } \\
500 \text { mg biweekly/No treatment. }\end{array}$ \\
\hline Sharami [18] & 2010 & Iran & 173 & 28-36 weeks gestation, tocolysis with MgSO4 & Progesterone 200 mg vaginally/Placebo. \\
\hline de Tejada & 2015 & $\begin{array}{l}\text { Switzerland and } \\
\text { Argentina }\end{array}$ & 384 & $\begin{array}{l}\text { 24-33 weeks gestation, tocolysis with } \\
\text { B-mimetics, antosiban, or calcium } \\
\text { channel blockers. }\end{array}$ & Progesterone 200 mg vaginally/Placebo. \\
\hline Briery $[16]$ & 2014 & USA & 45 & $\begin{array}{l}\text { 20-30 weeks gestation, tocolysis with } \\
\text { NSAIDS, nifedipine or MgSO4 }\end{array}$ & $\begin{array}{l}\text { 17-hydroxyprogesterone caporate } \\
250 \text { mg IM weekly/ Placebo }\end{array}$ \\
\hline Gargari [23] & 2012 & Iran & 110 & $\begin{array}{l}\text { 24-33 weeks gestation, tocolysis } \\
\text { with } \mathrm{MgSO} 4\end{array}$ & $\begin{array}{l}\text { Progesterone } 400 \text { mg vaginally/No } \\
\text { treatment }\end{array}$ \\
\hline Wood & 2017 & Canada & 41 & $\begin{array}{l}\text { 23-33 weeks gestation, after tocolysis } \\
\text { with NSAIDS or nifedipine or no tocolysis } \\
\text { and positive vaginal fetal fibronectin }\end{array}$ & Progesterone 200 mg vaginally/Placebo. \\
\hline
\end{tabular}


of the secondary outcomes, Appendix Table 4. There were no perinatal deaths. Only $50 \%$ of subjects returned their treatment diaries and unused capsules so reliable estimates of compliance could not be made.

\section{Meta-analysis}

The initial literature search initially identified 96 (Medline), 167 (Embase), 163 (PubMed) and 18 (Cochrane) abstracts. The updated literature search identified a further 60 abstracts. The details of the review process are presented in Fig. 1. Ultimately, 18 trials (including ours) were identified and 15 were included in the meta-analysis. The reasons for exclusion were: two trials were single dose progesterone treatment for acute tocolysis only not maintenance tocolysis $[9,10]$ and one was a trial of prophylactic 17hydroxyprogesterone caporate in women with previous premature delivery [11]. The details of the included trials are presented in Table 1. Two trials employed oral progesterone [12, 13], three used intra-muscular 17hydroxyprogesterone caporate [14-16], our trial and seven others used vaginal progesterone [17-23] and one trial compared intramuscular 17-hydroxyprogesterone caporate or vaginal progesterone to no treatment [24]. Eight authors were contacted by email requesting additional information regarding outcomes not reported in their manuscripts and responses were received from three. All the trials were reviewed for quality by two reviewers (SW, JR). Five were judged to be high quality and nine low quality (Table 2). Overall, treatment with progesterone reduced preterm birth less than 37 weeks gestation (OR 0.77, 95\% CI 0.62, 0.96). However, this was not statistically significant for the vaginal progesterone nor intra-muscular 17-hydroxyprogesterone caporate subgroups (Fig. 2). The proportion of births before 34 weeks gestation was also reduced with treatment (OR

Table 2 Quality assessment of randomized controlled trials of progesterone for maintenance tocolysis

\begin{tabular}{|c|c|c|c|c|c|c|c|}
\hline Study & $\begin{array}{l}\text { Randomization/Allocation } \\
\text { concealment method }\end{array}$ & Blinding & Compliance with treatment & $\begin{array}{l}\text { Post Randomization } \\
\text { Exclusions }\end{array}$ & $\begin{array}{l}\text { Intention to } \\
\text { Treat analysis }\end{array}$ & Quality & $\begin{array}{l}\text { Included in } \\
\text { meta-analysis }\end{array}$ \\
\hline Areia & "no allocation concealment" & No & $\begin{array}{l}\text { None discontinued } \\
\text { treatment }\end{array}$ & No & Yes & Low & Yes \\
\hline Borna & $\begin{array}{l}\text { Random number list, no } \\
\text { allocation concealment }\end{array}$ & No & Unclear & No & Yes & Low & Yes \\
\hline Choudhary & $\begin{array}{l}\text { Computer generated list, } \\
\text { "randomly allocated by } \\
\text { third party" }\end{array}$ & Yes & Unclear & $\begin{array}{l}\text { Yes, } 2 \text { in progesterone } \\
\text { group, } 3 \text { in placebo group }\end{array}$ & Yes & Low & Yes \\
\hline Facchinetti & $\begin{array}{l}\text { Computer generated list, } \\
\text { "managed by the senior } \\
\text { midwife" }\end{array}$ & No & $\begin{array}{l}\text { "Patients were } \\
\text { compliant" }\end{array}$ & No & Yes & Low & Yes \\
\hline Kamat & $\begin{array}{l}\text { Computer generated } \\
\text { random number table. } \\
\text { Unclear allocation } \\
\text { concealment }\end{array}$ & No & Unclear & $\begin{array}{l}\text { Yes, } 4 \text { in progesterone } \\
\text { group } 6 \text { in control. }\end{array}$ & Yes & Low & Yes \\
\hline Lotfalizadeh & No information provided. & No & Unclear & $?$ & $?$ & Low & Yes \\
\hline Noblot & $\begin{array}{l}\text { Randomized schedule } \\
\text { prepared by pharmacy }\end{array}$ & Yes & Unclear & None & Yes & High & Yes \\
\hline Palacio & $\begin{array}{l}\text { Centralized computer } \\
\text { randomization }\end{array}$ & Yes & Unclear & $\begin{array}{l}\text { Yes } 6 \text { in progesterone } \\
\text { group. }\end{array}$ & Yes & High & Yes \\
\hline Rozenberg & $\begin{array}{l}\text { Centralized computer } \\
\text { randomization. }\end{array}$ & No & & $\begin{array}{l}\text { Yes, } 1 \text { in progesterone } \\
\text { group and } 4 \text { in control. }\end{array}$ & Yes & Low & Yes \\
\hline Sharami & $\begin{array}{l}\text { "randomized into two } \\
\text { groups using the random } \\
\text { block allocation method" }\end{array}$ & Yes & Unclear & $\begin{array}{l}\text { Yes, } 6 \text { in progesterone } \\
\text { group, } 4 \text { in placebo }\end{array}$ & Yes & Low & Yes \\
\hline de Tejada & $\begin{array}{l}\text { Centralized computer } \\
\text { randomization. }\end{array}$ & Yes & $\begin{array}{l}4 \text { in progesterone and } 5 \\
\text { in placebo groups stopped } \\
\text { medication. Overall } 58 \% \\
\text { compliance }\end{array}$ & $\begin{array}{l}\text { Yes } 4 \text { in progesterone } \\
\text { group, } 2 \text { in placebo. }\end{array}$ & Yes & High & Yes \\
\hline Briery & $\begin{array}{l}\text { Sequentially numbered } \\
\text { sealed opaque envelopes }\end{array}$ & Yes & Unclear & None & Yes & High & Yes \\
\hline Gargari & Unclear & No & Unclear & Yes, 38 subjects & $?$ & Low & Yes \\
\hline Wood & $\begin{array}{l}\text { Pharmacy randomization } \\
\text { with schedule concealed } \\
\text { from clinicians. }\end{array}$ & Yes & Unclear & None & Yes & High & Yes \\
\hline
\end{tabular}


$0.80,95 \%$ CI $0.60,1.08)$ but this difference was not statistically significant (Fig. 3). Additionally, a statistically significant increase in latency to delivery was apparent for all three progesterone treatments (Fig. 4). Planned subgroup analysis by quality revealed that the results varied significantly between high and low quality trials (Figs. 5, 6 and 7). The pooled results of the low quality trials suggested a reduction in the risk of delivery less than 37 weeks (OR 0.47, 95\% CI 0.34, 0.64), less than 34 weeks (OR $0.55,95 \%$ CI $0.35,0.86$ ) and increased latency to delivery (15.97 days, 95\% CI 14.09, 17.84). However, the summary of high quality trials did not reveal any benefit for any of the outcomes: delivery less than 37 weeks (OR 1.23, 95\% CI 0.91, 1.67), delivery less than 34 weeks (OR 1.12, 95\% CI 0.74, 1.69) nor latency to delivery $(-0.95$ days, $95 \%$ CI $-5.54,3.64)$. Only five trials reported any perinatal deaths, 31 in the low quality trials and 9 in the high quality trials. Progesterone treatment was associated with a reduction in risk of perinatal death in the low quality trials: (OR $0.39,95 \%$ CI 0.17 , 0.87 ) but not the high quality trials: (OR $0.52,95 \% \mathrm{CI}$ $0.14,1.95)$.

\section{Discussion}

Neither our trial result nor the meta-analysis suggest progesterone is effective for maintenance tocolysis. Although the overall pooled analysis in the meta-analysis favors a treatment effect, the high quality studies do not. One previously published meta-analysis of vaginal progesterone for maintenance tocolysis concluded that treatment was associated with a reduced risk of prematurity and prolongation of pregnancy [25]. However, no subgroup analysis by study quality was reported. Overall, we feel that the results of the high quality studies are the most reliable indicator of a null treatment effect. If anything, it could be argued that these studies suggest a potential for harm with as the point estimates suggested an increase in prematurity and shorter latency with treatment. The substantial effect of trial quality that we observed has been reported previously. Several groups have found that poor allocation concealment and blinding influence results, usually, by increasing positive treatment effects [26-28]. Although some readers may prefer the results of the pooled analysis of all the trials, we would caution against this. The history

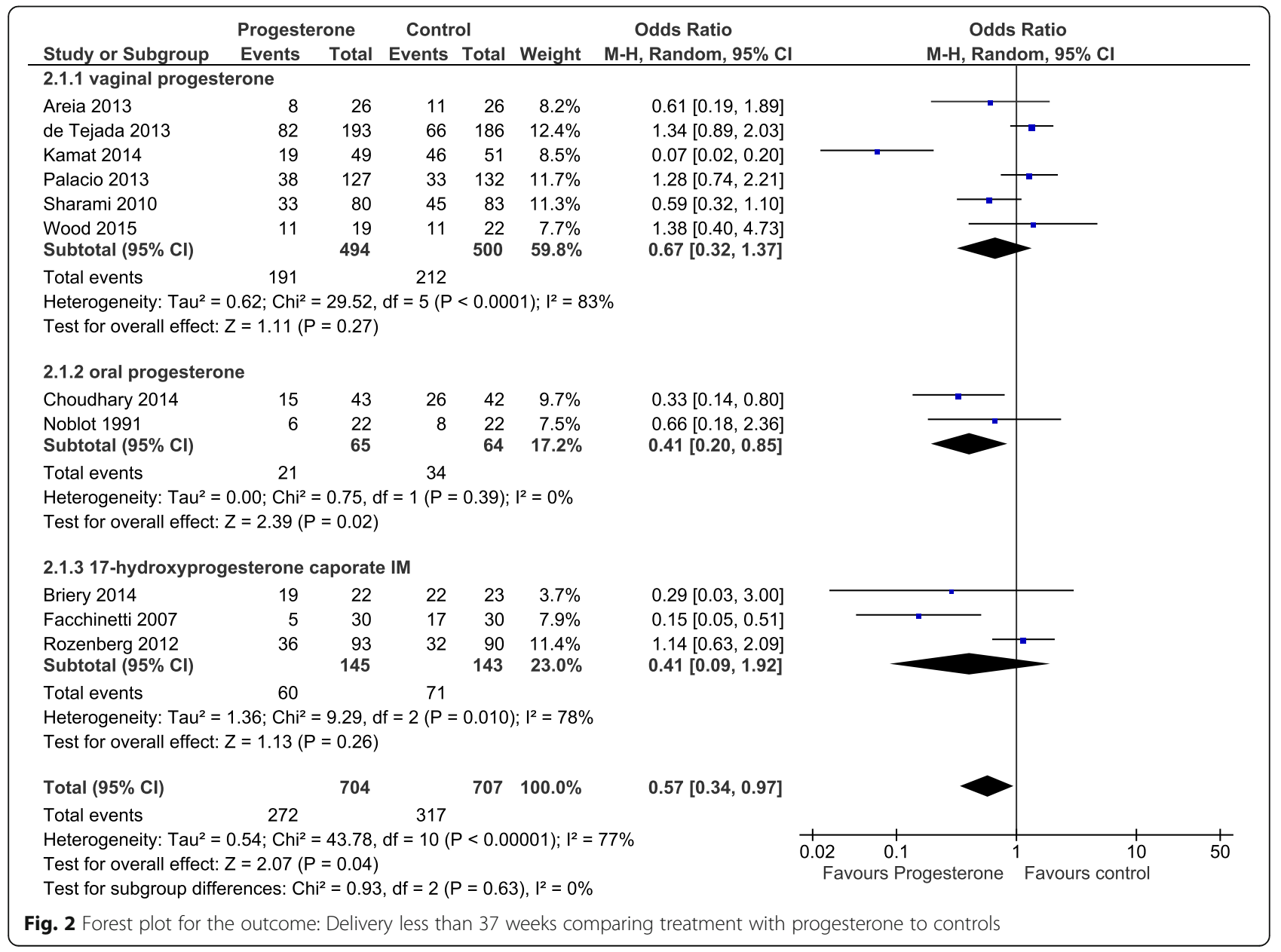




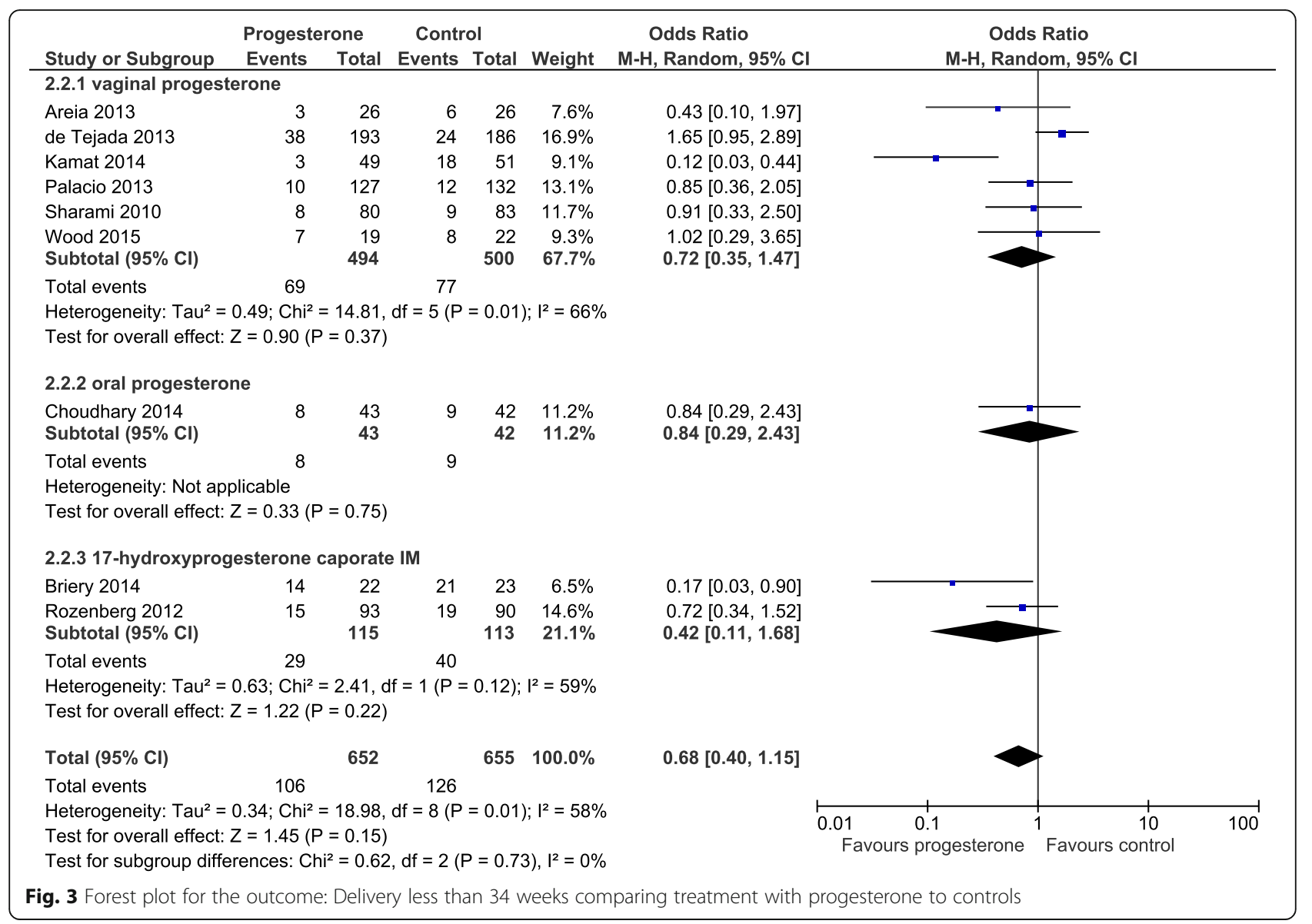

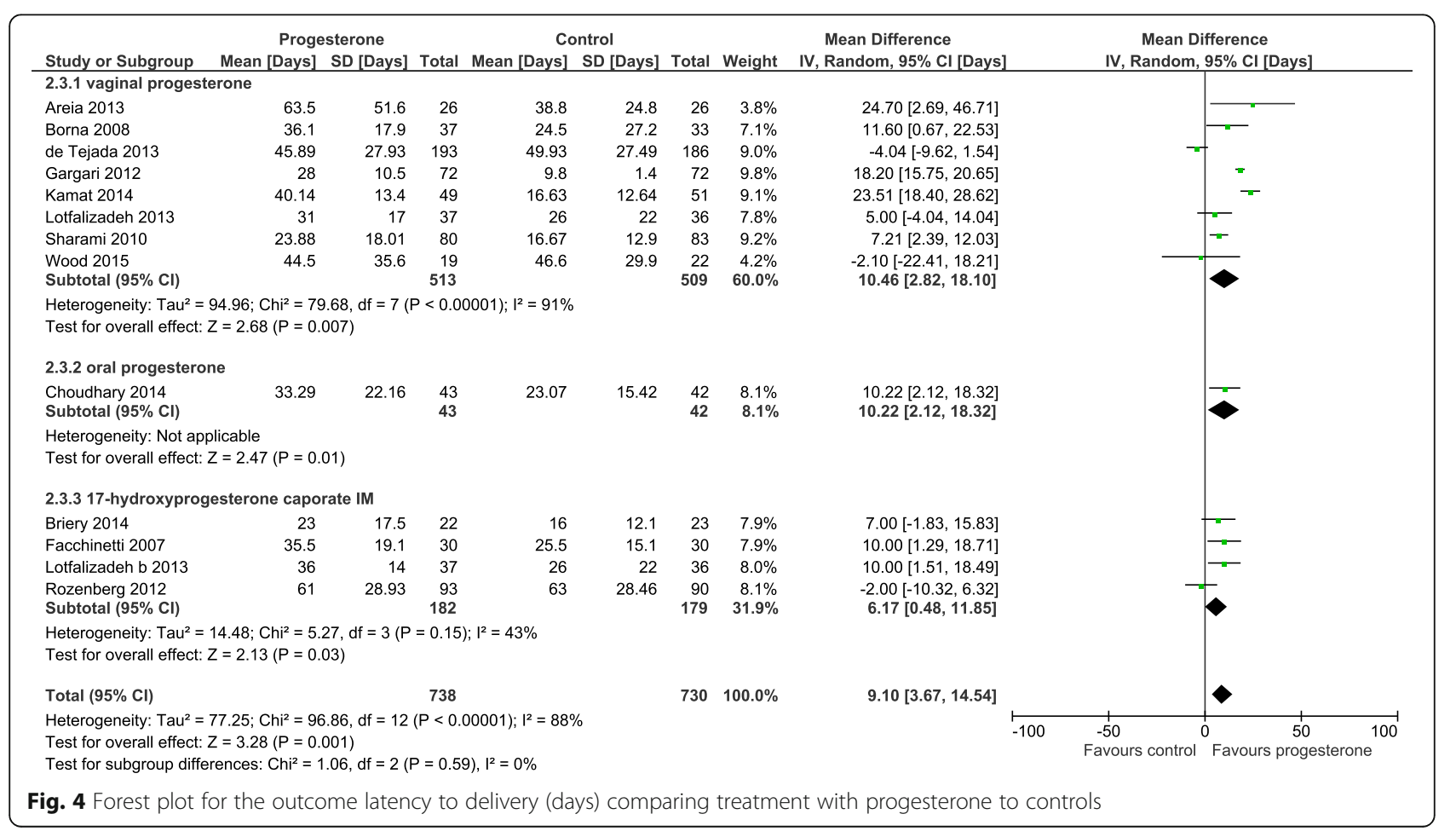




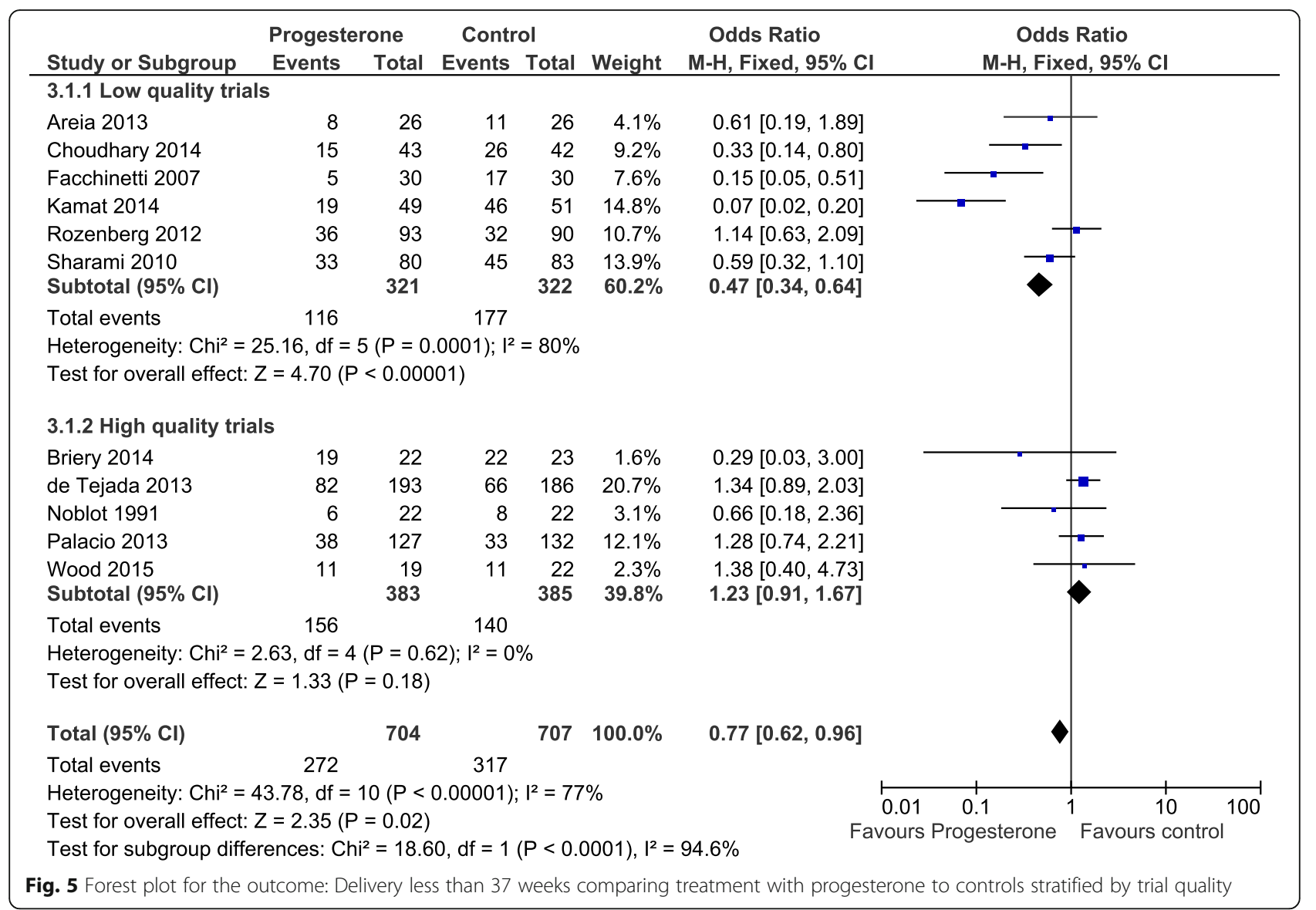

of clinical trials has taught trialists the importance of protecting their research from their own biases by using good study design. Therefore, results from studies with good design and execution are more likely to produces reliable estimates of effect. In this instance, such studies do not suggest progesterone, by any route, is an effective therapy for prolonging pregnancy in women who have arrested premature labor.

Still, alternative explanations should be considered for the negative results of both our trial and the meta-analysis. One typical issue, low power, is not one we feel is likely. Although latency to delivery is not necessarily, by itself, a clinically important endpoint, it should be a sensitive indicator of biologic effect. That we observe no discernible effect on latency in our trial and the summary of the high quality trials support a conclusion that progesterone is ineffective. It does remain a possibility that an effective progesterone dose has yet to be determined and future trials of increased doses may show positive results. Unfortunately, although our review found a fair number of studies that used higher doses of both vaginal and intra-muscular progesterone, none of these was high quality trial. A search of ClinicalTrials.gov only identified one additional, terminated, and unreported trial that used $400 \mathrm{mg}$ vaginal progesterone which recruited 7 subjects (NCT00946088). Poor patient compliance is also a potential explanation for our results. Regrettably, in our study, we were unable to reliably comment on compliance, as too few subjects returned their pill diaries or unused medications. This did not seem to be unique to our trial as very few of the studies reported any measures of patient compliance. While in the case of treatment with intra-muscular 17-hydroxyprogesterone caporate, poor compliance may be evident to the investigators, the same cannot be said of vaginal or oral routes.

\section{Conclusions}

In summary, our results do not support the routine use of progesterone, in any form, for maintenance tocolysis. However, further clinical trials with good measurement of patient compliance and higher doses of progesterone could be justified. 


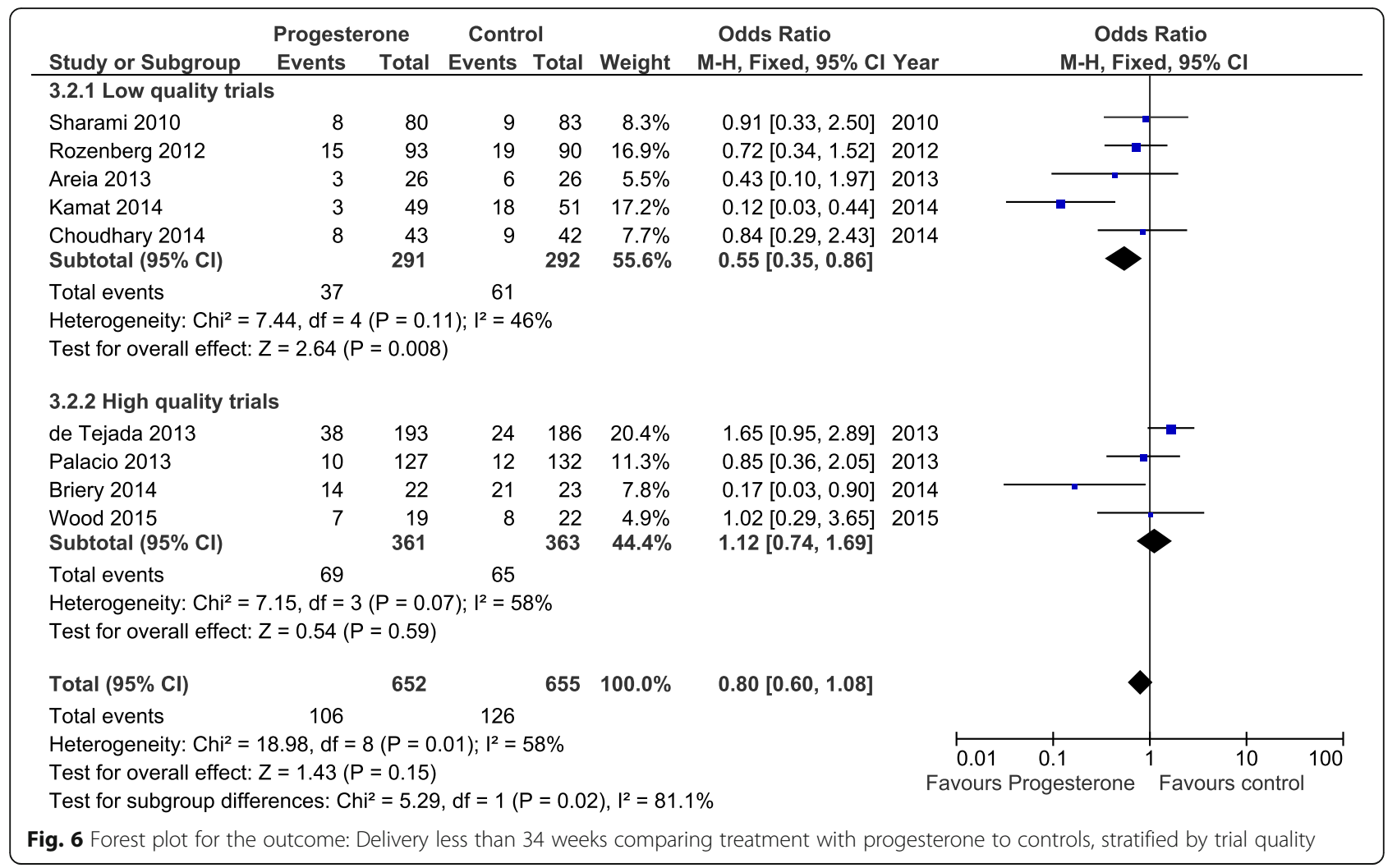

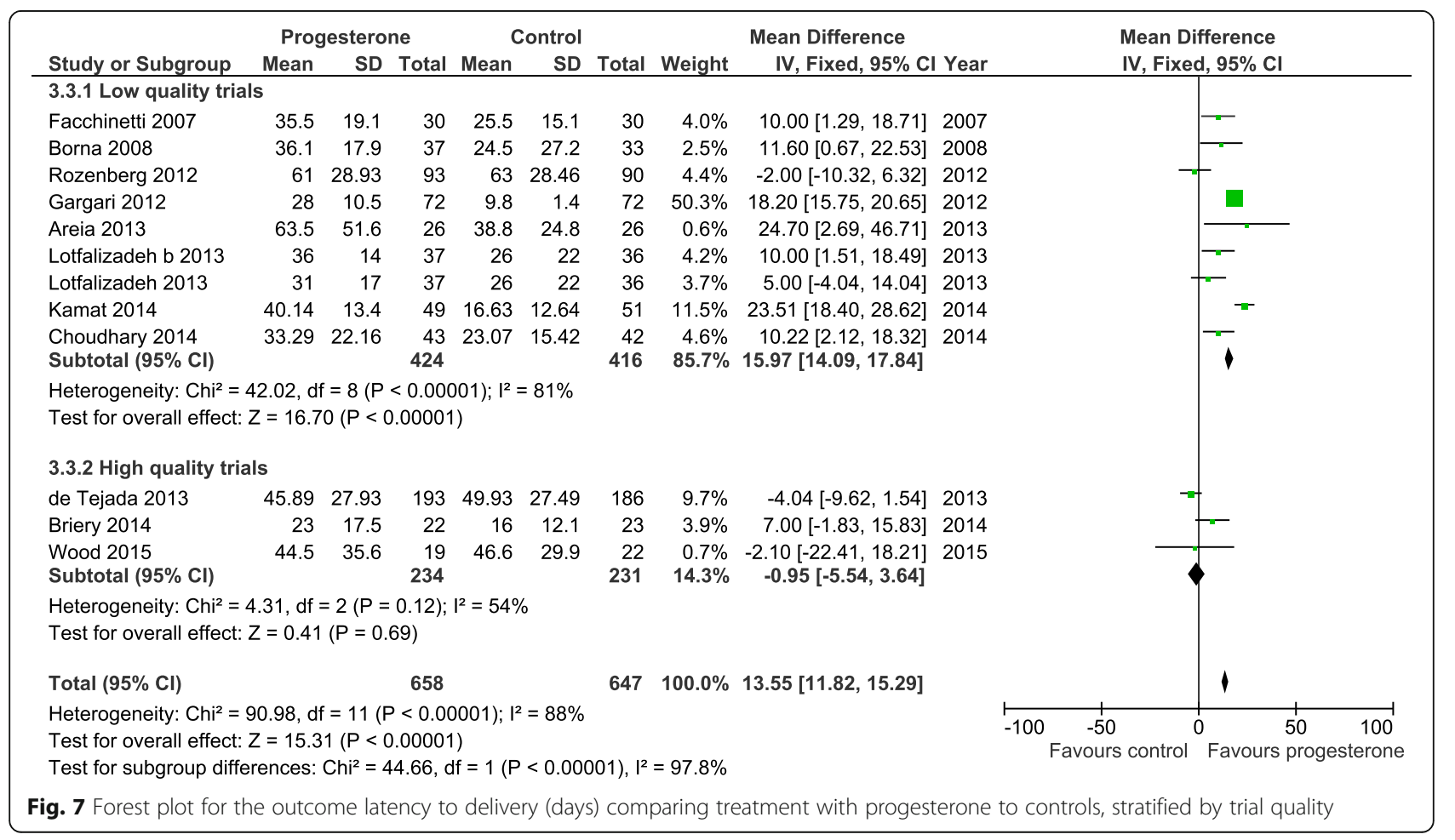




\section{Appendix}

Table 3 Patient Characteristics

\begin{tabular}{|c|c|c|}
\hline Characteristic & $\begin{array}{l}\text { Progesterone } \\
n=19\end{array}$ & $\begin{array}{l}\text { Placebo } \\
n=22\end{array}$ \\
\hline Mean Maternal age (years) & $\begin{array}{l}26.5 \text { (SD 3.9) } \\
\text { Range 20-34 }\end{array}$ & $\begin{array}{l}29.1 \text { (SD 5.9) } \\
\text { Range } 19 \text { to } 39\end{array}$ \\
\hline Mean Gestational age at randomization (weeks and days) & $\begin{array}{l}29^{+0}\left(\mathrm{SD} 2^{+2}\right) \\
\text { Range } 24^{+2} \text { to } 32^{+5}\end{array}$ & $\begin{array}{l}28^{+4}\left(\mathrm{SD} 2^{+5}\right) \\
\text { Range } 23^{+1} \text { to } 32^{+3}\end{array}$ \\
\hline \multicolumn{3}{|l|}{ Gravidity } \\
\hline 1 & $4(21.1 \%)$ & $7(31.8 \%)$ \\
\hline 2 & $9(47.4 \%)$ & $7(31.8 \%)$ \\
\hline 3 or more & $6(31.6 \%)$ & $8(36.4 \%)$ \\
\hline \multicolumn{3}{|l|}{ Parity } \\
\hline 0 & $6(31.6 \%)$ & $10(45.5 \%)$ \\
\hline 1 & $8(42.1 \%)$ & $7(31.8 \%)$ \\
\hline 2 or more & $5(26.3 \%)$ & $5(22.7 \%)$ \\
\hline \multicolumn{3}{|l|}{ Number of previous PTB $<37$ weeks } \\
\hline 0 & $10(58.8 \%)$ & $16(72.7 \%)$ \\
\hline 1 & $5(29.4 \%)$ & $3(13.6 \%)$ \\
\hline 2 & $2(11.8 \%)$ & $3(13.6 \%)$ \\
\hline Unknown & 2 & 0 \\
\hline \multicolumn{3}{|l|}{ Conception (this pregnancy) } \\
\hline Spontaneous & $14(93.3 \%)$ & $17(81.0 \%)$ \\
\hline Ovulation induction alone & $1(6.7 \%)$ & $3(14.3 \%)$ \\
\hline IVF & $0(0.0 \%)$ & $1(4.8 \%)$ \\
\hline Unknown & 4 & 1 \\
\hline \multicolumn{3}{|l|}{ Multiple reduction (before randomization) } \\
\hline No & $16(100 \%)$ & $22(100 \%)$ \\
\hline Unknown & 3 & 0 \\
\hline \multicolumn{3}{|c|}{ Pregnancy complications (this pregnancy, before or at time of randomization) } \\
\hline None & $3(17.6 \%)$ & $10(47.6 \%)$ \\
\hline Diabetes & $1(5.9 \%)$ & $0(0.0 \%)$ \\
\hline Uterine abnormality & $0(0.0 \%)$ & $1(4.8 \%)$ \\
\hline Previous AP bleed & $5(29.4 \%)$ & $3(14.3 \%)$ \\
\hline Recreational drugs & $0(0.0 \%)$ & 1 (4.8\%) \\
\hline Smoker & $6(35.3 \%)$ & 4 (19.0\%) \\
\hline Other ${ }^{a}$ & 7 (41.2\%) & 5 (23.8\%) \\
\hline Unknown & 2 & 1 \\
\hline
\end{tabular}

a Other in Group A includes cardiac disease; crohns/ileostomy/mult bowel resections; epilepsy/fam hx von willebrands; hypothyroidism/hx post partum depression; and limb girdle muscular dystrophy/ marginal placenta previa/prev thyroidectomy. Other in Group B includes depression/prev ruptured spleen; hx genital herpes; migraines/small septate uterus; depression/maternal grade 2 cardiac murmer; asthmatic; small subchorionic bleed noted on $8 \mathrm{w}$ US; and two prev cs 


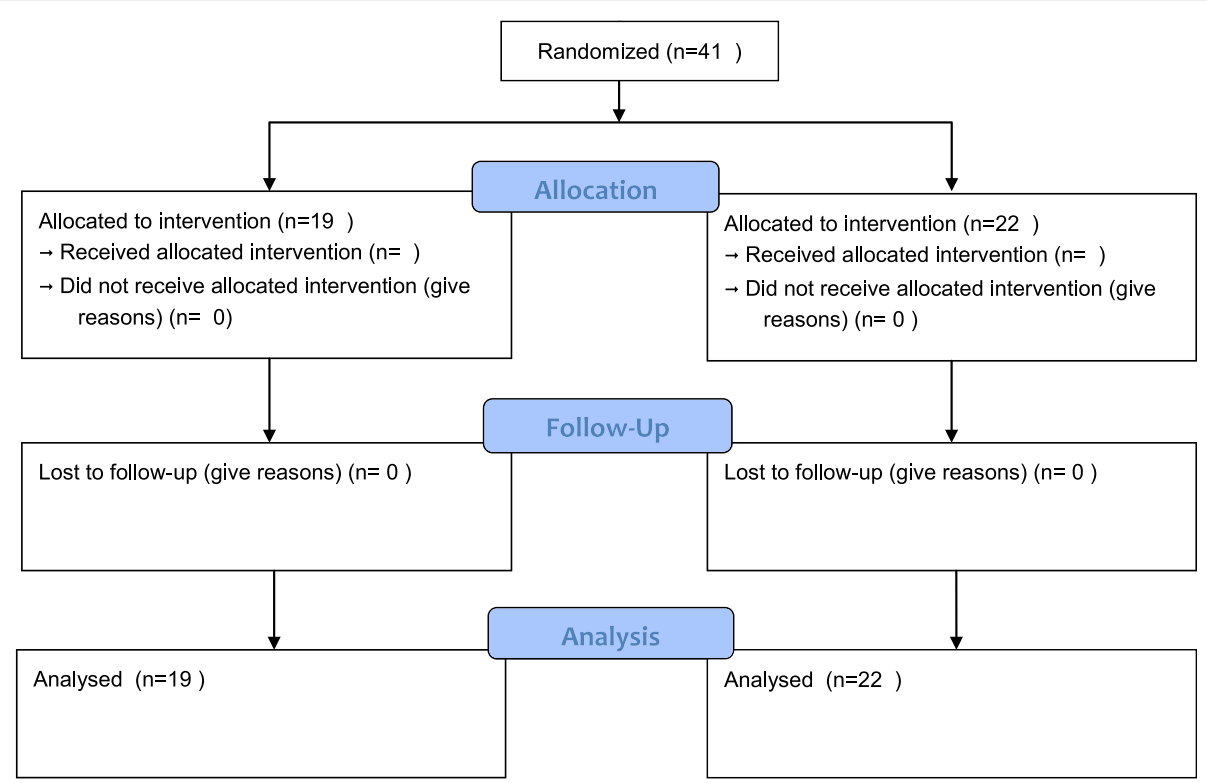

Fig. 8 Consort Diagram

Table 4 Outcomes to 28 days after delivery

\begin{tabular}{|c|c|c|c|c|}
\hline & $\begin{array}{l}\text { Progesterone } \\
n=19\end{array}$ & $\begin{array}{l}\text { Placebo } \\
n=22\end{array}$ & $p$-value* & $\begin{array}{l}\text { Median/Mean/Risk Difference } \\
\text { (95\% Confidence Interval)* }\end{array}$ \\
\hline \multicolumn{5}{|l|}{ Primary outcome } \\
\hline Median Gestational age at delivery (weeks and days) & $\begin{array}{l}36^{+2}\left(\mathrm{IQR} 7^{+4}\right) \\
\text { Range } 26^{+6} \text { to } 41^{+2}\end{array}$ & $\begin{array}{l}36^{+4}\left(\mathrm{IQR} 8^{+0}\right) \\
\text { Range } 24^{+3} \text { to } 41^{+2}\end{array}$ & 0.865 & $\begin{array}{l}-0^{+2} \\
\left(-3^{+1} \text { to } 2^{+3}\right)\end{array}$ \\
\hline Mean Latency from randomization to delivery (days) & $\begin{array}{l}44.5 \text { (SD 35.6) } \\
\text { Range } 0 \text { to } 113\end{array}$ & $\begin{array}{l}46.6(S D 29.9) \\
\text { Range } 2 \text { to } 116\end{array}$ & 0.841 & $\begin{array}{l}-2.1 \\
(-22.8 \text { to } 18.6)\end{array}$ \\
\hline \multicolumn{5}{|l|}{ Secondary outcomes } \\
\hline \multicolumn{5}{|l|}{ Maternal outcomes } \\
\hline Gestational age at delivery $<37$ weeks & $11(57.9 \%)$ & $11(50.0 \%)$ & 0.758 & $\begin{array}{l}7.9 \% \\
(-23.1 \% \text { to } 38.0 \%)\end{array}$ \\
\hline Gestational age at delivery $<35$ weeks & $8(42.1 \%)$ & $9(40.9 \%)$ & $>0.999$ & $\begin{array}{l}1.2 \% \\
(-29.5 \% \text { to } 31.4 \%)\end{array}$ \\
\hline Gestational age at delivery $<34$ weeks & $7(36.8 \%)$ & $8(36.4 \%)$ & $>0.999$ & $\begin{array}{l}0.5 \% \\
(-30.0 \% \text { to } 30.4 \%)\end{array}$ \\
\hline \multicolumn{5}{|l|}{ Tocolytics at any time during this pregnancy } \\
\hline Yes & $14(77.8 \%)$ & $16(84.2 \%)$ & 0.693 & \multirow{3}{*}{$\begin{array}{l}-6.4 \% \\
\text { (-36.3\% to } 26.3 \%)\end{array}$} \\
\hline No & $4(22.2 \%)$ & $3(15.8 \%)$ & & \\
\hline Unknown & 1 & 3 & & \\
\hline \multicolumn{5}{|l|}{ PPROM } \\
\hline Yes & $3(16.7 \%)$ & $4(18.2 \%)$ & \multirow[t]{3}{*}{$>0.999$} & \multirow{3}{*}{$\begin{array}{l}-1.5 \% \\
(-32.0 \% \text { to } 28.8 \%)\end{array}$} \\
\hline No & $15(83.3 \%)$ & $18(81.8 \%)$ & & \\
\hline Unknown & 1 & 0 & & \\
\hline \multicolumn{5}{|l|}{ Betamethasone treatment } \\
\hline Yes & 15 (93.8\%) & $18(94.7 \%)$ & \multirow[t]{3}{*}{$>0.999$} & \multirow{3}{*}{$\begin{array}{l}-1.0 \% \\
(-33.1 \% \text { to } 31.6 \%)\end{array}$} \\
\hline No & $1(6.3 \%)$ & $1(5.3 \%)$ & & \\
\hline Unknown & 3 & 3 & & \\
\hline \multicolumn{5}{|l|}{ Mode of delivery } \\
\hline Vaginal & $9(47.4 \%)$ & 16 (72.7\%) & 0.493 & $14.1 \%$ \\
\hline
\end{tabular}


Table 4 Outcomes to 28 days after delivery (Continued)

\begin{tabular}{|c|c|c|c|c|}
\hline Operative vaginal & $3(15.8 \%)$ & $1(4.6 \%)$ & & $(-16.5 \%$ to $43.2 \%)$ \\
\hline Cesarean Section & $7(36.8 \%)$ & $5(22.7 \%)$ & & \\
\hline \multicolumn{5}{|l|}{ Delivery complications } \\
\hline None & $15(83.3 \%)$ & $18(90.0 \%)$ & \multirow[t]{5}{*}{0.653} & \multirow{5}{*}{$\begin{array}{l}6.7 \% \\
(-24.7 \% \text { to } 38.1 \%)\end{array}$} \\
\hline Hypertension & $0(0.0 \%)$ & $1(5.0 \%)$ & & \\
\hline AP bleed & $0(0.0 \%)$ & $1(5.0 \%)$ & & \\
\hline Other $^{a}$ & $3(16.7 \%)$ & $0(0.0 \%)$ & & \\
\hline Unknown & 1 & 2 & & \\
\hline \multicolumn{5}{|l|}{ Infant outcomes } \\
\hline Median Birth weight (grams) & $\begin{array}{l}2625(\text { IQR 1340) } \\
\text { Range } 750 \text { to } 3766 \\
\text { (missing = 1) }\end{array}$ & $\begin{array}{l}2660 \text { (IQR 1555) } \\
\text { Range } 670 \text { to } 3955\end{array}$ & 0.734 & $\begin{array}{l}-105 \\
(-739 \text { to } 506)\end{array}$ \\
\hline \multicolumn{3}{|l|}{ Adverse outcomes } & \multirow[t]{4}{*}{0.732} & \multirow{4}{*}{$\begin{array}{l}9.5 \% \\
(-23.9 \% \text { to } 41.1 \%)\end{array}$} \\
\hline One or more & $10(66.7 \%)$ & $12(57.1 \%)$ & & \\
\hline None & $5(33.3 \%)$ & $9(42.9 \%)$ & & \\
\hline Unknown & 4 & 1 & & \\
\hline \multicolumn{5}{|c|}{ Description of outcomes (could be more than one) } \\
\hline Stillbirth/neonatal death & 0 & 0 & & \\
\hline BPD & 0 & 3 & & \\
\hline $\mathrm{IVH}$ & 0 & 0 & & \\
\hline NEC & 0 & 1 & & \\
\hline RDS & 4 & 7 & & \\
\hline Apnea/bradycardia & 1 & 2 & & \\
\hline Jaundice/hyperbilirubinemia & 4 & 6 & & \\
\hline Suspected sepsis & 2 & 2 & & \\
\hline Transient tachypnea & 1 & 2 & & \\
\hline Other $^{\mathrm{b}}$ & 8 & 20 & & \\
\hline On ventilator & 0 & 4 & & \\
\hline Median Baby length of stay (days) & $\begin{array}{l}6(\mathrm{IQR} 29) \\
\text { Range } 0 \text { to } 86 \\
\text { (missing = 3) }\end{array}$ & $\begin{array}{l}3 \text { (IQR 38) } \\
\text { Range } 1 \text { to } 127 \\
\text { (missing }=4 \text { ) }\end{array}$ & 0.903 & $\begin{array}{l}0 \\
(-15 \text { to } 10)\end{array}$ \\
\hline
\end{tabular}

a Other includes: 3rd degree tear, maternal pancreatitis, and assisted breech extraction

${ }^{b}$ Other in Group A includes: ventriculomegaly, admission to nicu (reason unknown), hypoglycemia, ROP, pulmonary insufficiency, GERD, esophageal atrenia, bilateral echogenic kidneys, PDA, positive enterobacter CONS tracheal aspirate, edema, hyperkalemia, anemia, metabolic acidosis, acute renal insufficiency, nephrocalcinosis, HMD, bilateral inguinal hernia, SGA, RT hydro ureter. Other in Group B includes: hypoglycemia, small cleft palate, hypovolemia, query infection, hypotension, minor hypospadius, oral aversion, SGA

* Fisher's exact test for categorical variables, Mann-Whitney U test or t-test for continuous variables; Risk difference and exact $95 \%$ confidence limits for categorical variables, Hodges-Lehmann estimation of location shift (median of differences) or difference in means and $95 \%$ confidence limits for continuous variables

\section{Abbreviations}

$\mathrm{Cl}$ : Confidence interval; OR: Odds ration; PPROM: Preterm premature rupture of membranes

\section{Funding}

The trial was funded by the Calgary Perinatal Funding Competitions which is funded by Ross Products a division of Abbott. Besins Healthcare (UK) provided the study medication and placebos. The authors are members of the Partnership for Research and Education in Mothers and Infants which has been funded by Ross Products a division of Abbott.

\section{Authors' contributions}

All authors contributed to the design of the study. SW, SR, JR, and RB designed the trial. SW and SR designed the review. SW and JR reviewed and scored all the abstracts. SW, RB and ST performed the statistical analysis and all the authors contributed to the interpretation of the results. SW drafted the manuscript which was reviewed by all of the authors. All authors read and approved the final manuscript.

\section{Ethics approval and consent to participate}

The study was approved by the local ethics review board REB15-1435 and a no objection letter was also obtained from Health Canada. Signed informed consent was obtained from all subjects.

\section{Consent for publication}

NA
Availability of data and materials

Data is available on request from the corresponding author. 


\section{Competing interests}

The authors declare that they have no competing interests.

\section{Publisher's Note}

Springer Nature remains neutral with regard to jurisdictional claims in published maps and institutional affiliations.

\section{Author details}

${ }^{1}$ Department of Obstetrics and Gynaecology, University of Calgary, 4th Floor, North Tower, Foothills Medical Centre 1441 - 29th Street NW, Calgary, AB T2N 2T9, Canada. ${ }^{2}$ Alberta Children's Hospital Research Institute, Foothills Medical Centre, Room, rm C211 1403 - 29th Street NW, Calgary, AB T2N 2T9, Canada. ${ }^{3}$ Department of Statistics, University of British Columbia, ESB rm 3146, 2207 Main Mall F512-4480 Oak Street, Vancouver, BC, Canada. ${ }^{4}$ Obstetrics \& Gynecology, University of Alberta, 5 S141 Lois Hole Hosp/ Robbins Pav/RAH, Edmonton, AB T5H 3V9, Canada.

Received: 22 April 2016 Accepted: 2 July 2017

Published online: 02 August 2017

\section{References}

1. Berkman N, Thorp JM, Lohr KN, Carey TS, Hartmann KE, Gavin NI, et al. Tocolytic treatment for the management of preterm labor: A review of the evidence. Am J Obstet Gynecol. 2003;188:1648-59.

2. Naik GN, Raman P, Bain E, Crowther CA. Maintenance therapy with calcium channel blockers for preventing preterm birth after threatened preterm labour. Cochrane Database Syst Rev. 2004;10:CD004071.

3. Humphrey RG, Bartfield MC, Carlan SJ, O'Brien WF, O'Leary TD, Triana T. Sulindac to prevent recurrent preterm labor: a randomized controlled trial. Obstet Gynecol. 2001;98(4):555-62.

4. Papatsonis DN, Flenady V, Liley HG. Maintenance therapy with oxytocin antagonists for inhibiting preterm birth after threatened preterm labour. Cochrane Database Syst Rev. 2013;10:CD005938.

5. Romero R, Nicolaides K, Conde-Agudelo A, Tabor A, O'Brien JM, Cetingoz E, et al. Vaginal progesterone in women with an asymptomatic sonographic short cervix in the midtrimester decreases preterm delivery and neonatal morbidity: a systematic review and metaanalysis of individual patient data. Am J Obstet Gynecol. 2012;206(2):124-19.

6. Meis PJ, Klebanoff MA, Thom E, Dombrowski MP, Sibai B, Moawad AH, et al. Prevention of recurrent preterm delivery by 17 alpha-hydroxyprogesterone caproate. N Engl J Med. 2003;348(24):2379-85.

7. Ross S, Milne J, Dwinnell S, Tang S, Wood S. Effect size needed to introduce progesterone and cervical cerclage into clinical practice to prevent premature birth. BMC Med Res Methodol. 2012;12(31)

8. Juni P, Altman DG, Egger M. Systematic reviews in health care: Assessing the quality of controlled clinical trials. BMJ. 2001:323(7303):42-6.

9. Tan PC, King AS, Vallikkannu N, Omar SZ. Single dose 17 alpha-hydroxyprogesterone caproate in preterm labor: a randomized trial. Arch Gynecol Obstet. 2012;285(3):585-90

10. Chawanpaiboon S, Pimol K, Sirisomboon R. Comparison of success rate of nifedipine, progesterone, and bed rest for inhibiting uterine contraction in threatened preterm labor. J Obstet Gynaecol Res. 2011;37(7):787-91.

11. Saghafi N, Khadem N, Mohajeri T, Shakeri MT. Efficacy of 17alpha-hydroxyprogesterone caproate in prevention of preterm delivery. J Obstet Gynaecol Res. 2011:37(10):1342-5

12. Noblot G, Audra P, Dargent D, Faguer B, Mellier G. The use of micronized progesterone in the treatment of menace of preterm delivery. Eur J Obstet Gynecol Reprod Biol. 1991;40(3):203-9.

13. Choudhary M, Suneja A, Vaid NB, Guleria K, Faridi MM. Maintenance tocolysis with oral micronized progesterone for prevention of preterm birth after arrested preterm labor. Int J Gynaecol Obstet. 2014;126(1):60-3.

14. Rozenberg P, Chauveaud A, Deruelle P, Capelle M, Winer N, Desbriere R, et al. Prevention of preterm delivery after successful tocolysis in preterm labor by 17 alpha-hydroxyprogesterone caproate: a randomized controlled trial. Am J Obstet Gynecol. 2012;206(3):206-9.

15. Facchinetti F, Paganelli S, Comitini G, Dante G, Volpe A. Cervical length changes during preterm cervical ripening: effects of 17-alpha-hydroxyprogesterone caproate. Am J Obstet Gynecol 421. 2007:196(5):453-4.

16. Briery CM, Klauser CK, Martin RW, Magann EF, Chauhan SP, Morrison JC. The use of 17-hydroxy progesterone in women with arrested preterm labor: a randomized clinical trial. J Matern Fetal Neonatal Med. 2014;27(18):1892-6.
17. Martinez De TB, Karolinski A, Ocampo MC, Laterra C, Hosli I, Fernandez D, et al. Prevention of preterm delivery with vaginal progesterone in women with preterm labour (4P): randomised double-blind placebo-controlled trial. BJOG Int J Obstet Gynaecol. 2015;122(1):80-91.

18. Sharami SH, Zahiri Z, Shakiba M, Milani F. Maintenance therapy by vaginal progesterone after threatened idiopathic preterm labor: A randomized placebo-controlled double-blind trial. Int J Fertil Steril. 2010;4(2):45-50.

19. Palacio M, Cobo T, Antolin E, Ramirez M, Cabrera F, De Rosales FM et al. Vaginal progesterone as maintenance treatment after an episode of preterm labor (PROMISE Study): A randomized, double blinded, placebocontrolled trial. Am J Obstet Gynecol. 2013;Conference(var.pagings):S10-S11.

20. Kamat S, Veena P, Rani R. Comparison of nifedipine and progesterone for maintenance tocolysis after arrested preterm labour. J Obstet Gynaecol. 2014;34(4):322-5.

21. Borna S, Sahabi N. Progesterone for maintenance tocolytic therapy after threatened preterm labour: a randomised controlled trial. Aust N Z J Obst Gynaecol. 2008:48(1):58-63.

22. Areia A, Fonseca E, Moura P. Progesterone use after successful treatment of threatened pre-term delivery. J Obstet Gynaecol. 2013;33:678-81.

23. Gargari SS, Habibolahi M, Zonobi ZKZ, Sarfjoo FS, Robati AK, Etemad R, et al. Outcome of Vaginal Progesterone as a Tocolytic Agent: Randomized Clinical Trial. ISRN Obstet Gynecol. 2012;2012:607906.

24. Lotfalizadeh M, Ghomian N, Reihani A. The effects of progesterone therapy on the gestation length and reduction of neonatal complications in patients who had received tocolytic therapy for acute phase of preterm labor. Iran Red Crescent Med J. 2013;15(10):e7947.

25. Suhag A, Saccone G, Berghella V. Vaginal progesterone for maintenance tocolysis: a systematic review and metaanalysis of randomized trials. Am J Obstet Gynecol. 2015;213:479-87.

26. Odgaard-Jensen J, Vist GE, Timmer A, Kunz R, Akl EA, Schunemann H, et al. Randomisation to protect against selection bias in healthcare trials. Cochrane Database Syst Rev. 2011;4:MR000012.

27. Herbison P, Hay-Smith J, Gillespie WJ. Different methods of allocation to groups in randomized trials are associated with different levels of bias. A meta-epidemiological study. J Clin Epidemiol. 2011;64(10):1070-5.

28. Savovic J, Jones HE, Altman DG, Harris RJ, Juni P, Pildal J, et al. Influence of reported study design characteristics on intervention effect estimates from randomized, controlled trials. Ann Intern Med. 2012;157(6):429-38.

\section{Submit your next manuscript to BioMed Central and we will help you at every step:}

- We accept pre-submission inquiries

- Our selector tool helps you to find the most relevant journal

- We provide round the clock customer support

- Convenient online submission

- Thorough peer review

- Inclusion in PubMed and all major indexing services

- Maximum visibility for your research

Submit your manuscript at www.biomedcentral.com/submit
) Biomed Central 